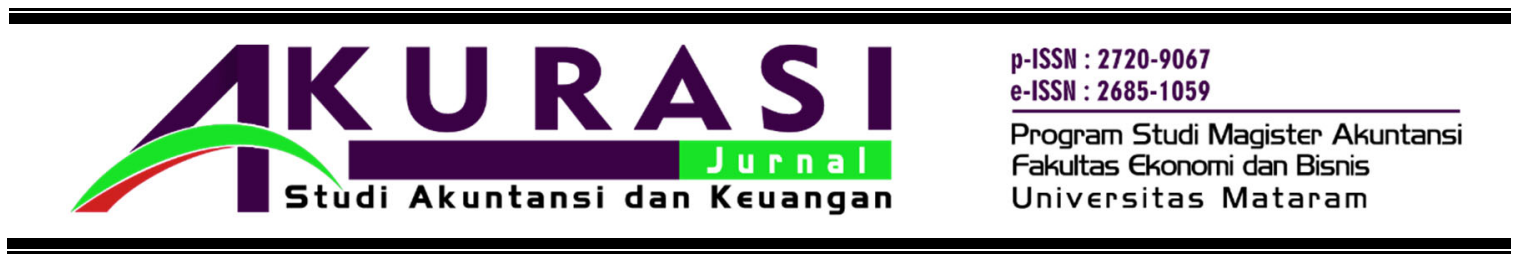

\title{
PERAN KINERJA KEUANGAN DALAM MEMODERASI PENGARUH GOOD CORPORATE GOVERNANCE TERHADAP NILAI PERUSAHAAN SEKTOR PERBANKAN TERDAFTAR DI BURSA EFEK INDONESIA
}

I Gusti Ayu Gita Kusuma Wardhani

FEB Universitas Mataram, email : igstayugita@gmail.com

INFORMASI ARTIKEL

Article history:

Dikirim : 22 Juli 2019

Revisi pertama : 19 September 2019

Diterima: 24 September 2019

Tersedia online : 15 Desember 2019

\section{ABSTRAK}

Tujuan dari penelitian ini adalah untuk menguji pengaruh good corporate governance terhadap nilai perusahaan, serta menguji interaksi kinerja keuangan dalam hubungan antara good corporate governance terhadap nilai perusahaan. Kinerja keuangan diukur menggunakan Loan to Deposit Ratio (LDR), sedangkan nilai perusahaan diproksikan dengan Tobin's Q. Good corporate governance diproksikan dengan menggunakan kepemilikan institusional, kepemilikan manajerial dan komisaris independen. Ukuran perusahaan dan reputasi bank diuji sebagai variabel kontrol. Penelitian dilakukan pada perusahaan sektor perbankan di Bursa Efek Indonesia. Jumlah sampel sejumlah 167 digunakan selama tahun pengamatan 2015-2018. Data dianalisis menggunakan uji Moderated Regression Analysis. Hasil penelitian menunjukkan bahwa kepemilikan institusional, kepemilikan manajerial dan komisaris independen tidak berpengaruh signifikan terhadap nilai perusahaan. Interaksi LDR tidak dapat memperkuat pengaruh good corporate governance terhadap nilai perusahaan. Namun demikian ukuran perusahaan dan reputasi bank berpengaruh signifikan terhadap nilai perusahaan.

Kata Kunci: nilai perusahaan, good corporate governance, kinerja keuangan.

\section{ABSTRACT}

The purpose of this study is to analyze the effect of good corporate governance on corporate value, and also discuss the interaction of financial performance in the relationship between good corporate governance on corporate value. Financial performance is measured using a Loan to Deposit Ratio (LDR), while the company's value is proxied by Tobin Q. Good corporate governance is proxied using institutional ownership, managerial ownership and independent commissioners. Bank size and bank reputation were tested as control variable. This research was conducted at banking sector companies on the Indonesia Stock Exchange. The number of samples used was 167 samples from 2015-2018. Data were analyzed using the Moderated Regression Analysis test. The results showed that institutional ownership, managerial ownership and independent commissioners were not significant to the firm's value. LDR interactions cannot support the effect of good corporate governance on firm value. However, bank size and bank reputation have a significant effect on corporate value.

Keywords: corporate value, good corporate governance, financial performance. 


\section{Pendahuluan}

Penerapan prinsip good corporate governance dalam dunia usaha sangat penting bagi perkembangan bisnis dalam menghadapi persaingan global sekarang ini (Halini, 2012). Perhatian yang meningkat tertuju pada good corporate governance akibat terjadinya krisis moneter yang terjadi di negara-negara Asia pada tahun 1997. Semenjak terjadinya krisis tersebut, telah menghancurkan berbagai sendi perekonomian salah satunya pada sektor perbankan yang menyebabkan menurunnya kinerja perbankan nasional yang menimbulkan kesulitan likuiditas akibat hancurnya Pasar Uang Antar Bank (Pratiwi, 2018). Salah satu penilaian faktor good corporate governance termuat dalam Surat Edaran No.15/15/DPNP/2013 yang menyatakan bahwa Bank Indonesia menyempurnakan metode penilaian Tingkat Kesehatan Bank Umum yaitu dengan menggunakan pendekatan risiko (Risk Based Bank Rating/RBBR) baik secara individual maupun secara konsolidasi. Pengaturan tersebut dilakukan agar perbankan di Indonesia dapat beroperasi secara sehat, sehingga memberikan kontribusi untuk meningkatkan pertumbuhan ekonomi nasional dengan menggerakkan sektor riil (Azzahrah, 2014).

Good corporate governance berperan dalam mengendalikan dan mengatur perusahaan guna menciptakan nilai tambah bagi semua pihak yang berkepentingan sebagai bentuk pelaksanaan dalam mewujudkan perusahaan yang sehat. Good corporate governance merupakan pedoman bagi manajer untuk mengelola perusahaan yang dapat menguntungkan semua pihak sehingga dapat memperkuat kinerja keuangan perusahaan yang apabila tidak ditangani secara professional, transparan dan hati-hati akan menimbulkan risiko dan permasalahan bagi perusahaan. Suprayitno dkk. (2016) mendefinisikan bahwa good corporate governance sebagai struktur, sistem dan proses yang digunakan oleh dewan komisaris dan direksi guna memberikan nilai tambah perusahaan yang berkesinambungan dalam jangka panjang. Dengan adanya mekanisme good corporate governance tersebut diharapkan dapat memonitor kinerja manajer perusahaan serta proses pengawasan pelaporan keuangan akan menjadi lebih efektif, sehingga dapat memperbaiki kinerja perusahaan dan meningkatkan nilai perusahaan. Memaksimalkan nilai perusahaan menjadi sangat penting, karena dengan memaksimalkan nilai perusahaan berarti juga memaksimalkan kemakmuran bagi pemegang saham yang merupakan tujuan utama perusahaan (Hery, 2017:6).

Nilai perusahaan yang tinggi menjadi keinginan para pemilik perusahaan, sebab dengan nilai perusahaan yang tinggi menunjukkan kemakmuran pemegang saham juga tinggi (Hamdani, 2016:138). Namun demikian dalam proses memaksimalkan nilai perusahaan akan muncul konflik kepentingan antara manajer dan pemegang saham (pemilik perusahaan) yang sering disebut agency problem. Hal tersebut terjadi karena manajer (agent) bisa jadi lebih mengutamakan kepentingan pribadi, sebaliknya pemegang saham (principal) tidak sejalan dengan kepentingan pribadi dari manajer karena apa yang dilakukan manajer tersebut akan menambah biaya bagi perusahaan sehingga menyebabkan penurunan keuntungan perusahaan dan berpengaruh terhadap harga saham sehingga menurunkan nilai perusahaan (Jensen \& Meckling, 1976). Adanya kepemilikan saham oleh manajemen, kepemilikan saham oleh institusional dan komisaris independen maka dapat mengurangi agency problem tersebut. 
Penelitian tentang pengaruh mekanisme good corporate governance terhadap nilai perusahaan telah dilakukan dalam beberapa studi dan ditemukannya hasil yang beragam. Penelitian Dewi dan Nugrahanti (2014) menunjukkan kepemilikan institusional dan kepemilikan manajerial tidak berpengaruh terhadap nilai perusahaan, sedangkan dewan komisaris independen berpengaruh positif terhadap nilai perusahaan. Sejalan dengan studi sebelumnya, penelitian Azzahrah (2014) juga menunjukkan bahwa kepemilikan manajerial dan dewan komisaris tidak berpengaruh terhadap nilai perusahaan. Namun demikian studi Muryati dan Suardikha (2014) menemukan hasil bahwa kepemilikan manajerial, kepemilikan institusional dan dewan komisaris independen berpengaruh positif terhadap nilai perusahaan. Penelitian lainnya yang dilakukan oleh Purwaningtyas (2011) menunjukkan bahwa dewan komisaris independen tidak berpengaruh terhadap nilai perusahaan, namun kepemilikan manajerial dan kepemilikan institusional berpengaruh positif terhadap nilai perusahaan. Temuan penelitian Utami dan Muslih (2018) mengungkapkan bahwa kepemilikan institusional, komisaris independen, dan komite audit berpengaruh signifikan terhadap nilai perusahaan. Hasil penelitian terdahulu yang masih kontradiktif mendorong peneliti untuk menguji dan menganalisis kembali dalam setting sektor keuangan perbankan yang memiliki karakteristik keuangan dan lingkungan bisnis yang berbeda.

Penelitian ini menginternalisasi kinerja keuangan yang diproksikan dengan Loan to Deposit Ratio (LDR) sebagai variabel pemoderasi serta variabel kontrol berupa ukuran perusahaan dan reputasi bank. Rasio perbankan yang diukur dengan LDR merupakan faktor yang mempengaruhi nilai perusahaan karena dengan pengelolaan kredit yang salah berpotensi menyebabkan pendapatan perusahaan berkurang sehingga berdampak bagi nilai perusahaan. Dengan meningkatnya kinerja perusahaan diharapkan juga dapat meningkatkan harga saham perusahaan sebagai indikator dari nilai perusahaan, sehingga peningkatan nilai perusahaan dapat tercapai. Jika rasio LDR bank berada pada standar yang ditetapkan oleh Bank Indonesia, maka laba yang diperoleh oleh bank tersebut akan meningkat dengan asumsi bank tersebut mampu menyalurkan kreditnya dengan efektif (Ismiawati, 2018). Argumentasi ini sejalan dengan penelitian Halimah dan Komariah (2017) serta Repi dkk (2016) yang menunjukkan bahwa LDR berpengaruh signifikan terhadap nilai perusahaan. Sebagai suatu bisnis yang berbasis kepercayaan masyarakat maka penerapan good corporate governance sangat penting bagi bank untuk menjamin bahwa dana yang disimpan oleh masyarakat akan dikelola secara profesional, transparan dan hati-hati dalam bentuk penyaluran kredit yang efektif dengan meminimalkan risiko bagi nasabah bank.

\section{Kerangka Teoretis Dan Pengembangan Hipotesis}

Teori keagenan atau Agency Theory pertama kali diungkapkan oleh Jensen dan Meckling (1976) yang mendefinisikan hubungan keagenan sebagai sebuah kontrak antara satu orang atau lebih (principal) dengan orang lain (agent), untuk melakukan beberapa layanan atas nama mereka dimana principal melimpahkan wewenang kepada agent dalam pengambilan keputusan. Agency Theory yang menekankan pentingnya pemilik perusahaan (pemegang saham) menyerahkan pengelolaan perusahaan kepada tenaga-tenaga profesional (agents) yang lebih mengerti dalam menjalankan bisnis sehari-hari (Sutedi, 2011:13). Dalam hal ini hubungan keagenan (agency relationship) terjadi ketika satu atau lebih individu yang disebut dengan principal menyewa individu atau organisasi lainnya yang disebut sebagai 
agent. Konflik kepentingan antara pemilik dan agen dapat terjadi karena kemungkinan agent tidak selalu berbuat sesuai dengan kepentingan dari principal (Hamdani, 2016:30).

Hubungan keagenan dapat menimbulkan masalah keagenan (agency problem). Faktor adanya agency problem adalah karena adanya asimetri informasi. Agent cenderung memiliki kemampuan mengendalikan informasi terkait perusahaan dibandingkan dengan principal (Hamdani, 2016:17). Konflik kepentingan antara pemilik dan agent terjadi karena kemungkinan agent tidak selalu melakukan pekerjaan sesuai dengan kepentingan principal, sehingga memicu biaya keagenan (agency cost). Biaya keagenan (agency cost) adalah biaya yang dikeluarkan pemilik untuk mengatur dan mengawasi kinerja para manajer sehingga agent bekerja untuk kepentingan terbaik perusahaan.

Dalam menjalankan perannya sebagai fungsi intermediasi antara pemilik dana dan pengguna dana, bank memainkan peranan ganda jika dikaji dari teori keagenan. Bank memainkan perannya sebagai agent saat menghimpun dana dari masyarakat. Dalam hal ini bank harus dapat meyakinkan para investor bahwa dana mereka aman dan akan terus bertambah setiap waktu dalam perannya melayani investor sebagai principal. Bank juga berperan sebagai principal saat menyalurkan dananya kepada masyarakat dalam berbagai bentuk layanan perbankan, dimana dana tersebut harus diawasi dan terjamin dapat dikembalikan oleh pengguna kredit dalam perannya sebagai agent.

\section{Pengembangan Hipotesis}

\section{Pengaruh Kepemilikan Institusional Terhadap Nilai Perusahaan}

Kepemilikan institusional memiliki peranan penting dalam meminimalisir konflik keagenan yang terjadi antara manajer dan pemegang saham. Keberadaan investor institusional dianggap mampu menjadi mekanisme monitoring yang efektif dalam setiap keputusan yang diambil oleh manajer. Monitoring yang dilakukan mampu mensubtitusi biaya keagenan, sehingga biaya keagenan menurun dan nilai perusahaan dapat meningkat (Purwaningtyas, 2011). Dengan adanya kepemilikan oleh institusional akan mendorong peningkatan pengawasan yang lebih optimal terhadap kinerja manajemen, sehingga manajemen akan lebih berhati-hati dalam mengambil keputusan. Semakin besar kepemilikan institusional maka semakin efisien pemanfaatan aktiva perusahaan dan dengan pengawasan efektif yang dilakukan institusi terhadap perusahaan. Melalui kepemilikan oleh institusi diharapkan dapat bertindak sebagai pencegahan terhadap pemborosan yang dilakukan oleh manajemen yang dapat merugikan pemegang saham. Dengan demikian dapat meminimalkan biaya-biaya yang dikeluarkan manajer untuk kepentingan pribadi yang dapat merugikan pemegang saham.

Kepemilikan institusional merupakan pemegang saham mayoritas yang ada di perusahaan. Studi Muryati dan Suardikha (2014) serta Purwaningtyas (2011) menunjukkan bahwa kepemilikan institusional berpengaruh positif pada nilai perusahaan. Dengan semakin meningkatnya kepemilikan oleh institusi maka fungsi monitoring dalam perusahaan semakin meningkat sehingga akan berkontribusi pada perbaikan nilai perusahaan. Berdasarkan argumentasi tersebut maka diajukan hipotesis sebagai berikut :

$\mathrm{H}_{1}$ : Kepemilikan institusional berpengaruh positif terhadap nilai perusahaan.

\section{Pengaruh Kepemilikan Manajerial Terhadap Nilai Perusahaan}

Agency Theory mengargumentasikan bahwa pemisahan antara kepemilikan dan pengelolaan perusahaan dapat menimbulkan konflik keagenan yang disebabkan principal dan 
agent mempunyai kepentingan sendiri-sendiri yang saling bertentangan karena agent dan principal berusaha memaksimalkan utilitasnya masing-masing (Dewi dan Nugrahanti, 2014). Jensen dan Meckling (1976) mengatakan untuk mengurangi konflik keagenan antara agent dan principal dapat dilakukan dengan cara meningkatkan kepemilikan saham oleh manajer di perusahaan. Kepemilikan oleh pihak manajerial akan mendorong manajer bekerja terbaik untuk kepentingan terbaik bagi perusahaan sehingga dapat meningkatkan nilai perusahaan.

Kepemilikan manajerial merupakan kepemilikan saham oleh manajemen perusahaan yang diukur dengan persentase jumlah saham yang dimiliki oleh perusahaan (Hery, 2017:96). Hasil penelitian Purwaningtyas (2011) menyatakan bahwa kepemilikan manajerial berpengaruh terhadap nilai perusahaan. Sejalan dengan penelitian-penelitian sebelumnya, Muryati dan Suardikha (2014) mengungkapkan bahwa kepemilikan manajerial berpengaruh positif pada nilai perusahaan. Dengan proporsi kepemilikan yang cukup tinggi, maka manajer akan merasa ikut memiliki perusahaan, sehingga akan berusaha semaksimal mungkin melakukan tindakan-tindakan yang dapat memaksimalkan kemakmurannya. Sebagai bagian dari kepemilikan perusahaan, maka manajemen cenderung bekerja terbaik untuk kepentingan terbaik perusahaan sehingga berdampak positif terhadap peningkatan nilai perusahaan. Berdasarkan argumentasi tersebut maka diajukan hipotesis sebagai berikut :

$\mathrm{H}_{2}$ : Kepemilikan manajerial berpengaruh positif terhadap nilai perusahaan.

\section{Pengaruh Komisaris Independen Terhadap Nilai Perusahaan}

Berdasarkan argumentasi teori keagenan, kehadiran komisaris independen merupakan mekanisme yang diharapkan dapat melakukan pengawasan dan mengontrol konflik kepentingan antara controlling shareholders dan minority shareholders sehingga terjadi efisiensi dalam manajemen perusahaan. Komisaris independen dapat digunakan untuk mengurangi masalah keagenan karena komisaris independen dapat mengkomunikasikan tujuan dan keinginan pemegang saham kepada para manajer (Hendratni dkk, 2018).

Dewan komisaris merupakan inti dari corporate governance yang ditugaskan untuk menjamin strategi perusahaan, mengawasi manajer dalam mengelola perusahaan, serta mewajibkan terlaksananya akuntabilitas (Purwaningtyas, 2011). Keberadaan komisaris independen diharapkan dapat meningkatkan efektifitas pengawasan dan mengupayakan meningkatkan kualitas dari laporan keuangan. Adanya pengawasan yang baik akan meminimalisir tindakan kecurangan yang dilakukan manajemen dalam pelaporan keuangan. Dengan demikian kualitas laporan keuangan juga semakin baik dan menyebabkan investor percaya untuk menanamkan modal di perusahaan tersebut sehingga harga saham perusahaan akan lebih tinggi dan nilai perusahaan semakin meningkat (Dewi dan Nugrahanti, 2014).

Semakin meningkat jumlah komisaris independen maka nilai perusahaan akan meningkat (Subowo, 2014 dalam Utami dan Muslih, 2018). Temuan penelitian tersebut didukung oleh studi Utami dan Muslih (2018) bahwa komisaris independen berpengaruh positif terhadap nilai perusahaan yang sejalan dengan penelitian Muryati dan Suardikha (2014) yang memperoleh hasil penelitian bahwa dewan komisaris independen berpengaruh positif pada nilai perusahaan. Berdasarkan argumentasi tersebut maka diajukan hipotesis sebagai berikut:

$\mathrm{H}_{3}$ : Komisaris independen berpengaruh positif terhadap nilai perusahaan. 


\section{Moderasi Kinerja Keuangan, Good Corporate Governance dan Nilai Perusahaan}

Munculnya konsep good corporate governance berawal dari adanya masalah keagenan, yaitu adanya perbedaan kepentingan antara principal dan agent, sehingga menimbulkan biaya agensi. Penerapan mekanisme GCG diharapkan dapat mengurangi munculnya konflik kepentingan yang sering disebut agency problem dalam meningkatkan kinerja keuangan dan memaksimalkan nilai perusahaan. Kinerja keuangan mempunyai arti sebagai salah satu aspek yang berkaitan dengan pengambilan keputusan, dapat dipertanggungjawabkan dan dapat diterima secara rasional apabila ada indikasi yang ditunjukkan oleh suatu analisis keuangan yang sifatnya akurat dan tepat (Halini, 2012).

Penerapan GCG juga dinilai dapat meningkatkan nilai perusahaan yang merupakan suatu prestasi, karena dengan meningkatnya nilai perusahaan maka kesejahteraan pemilik dan pemegang saham juga akan meningkat (Triutari dan Wirawati, 2018). Penelitian Utami dan Muslih (2018) menyatakan bahwa GCG (kepemilikan institusional, komisaris independen, dan komite audit) sebelum dan sesudah dimoderasi oleh kinerja keuangan berpengaruh signifikan terhadap nilai perusahaan. Mekanisme GCG dalam penelitian ini diproksikan oleh kepemilikan institusional, kepemilikan manajerial dan komisaris independen.

Perusahaan akan berusaha untuk meningkatkan kinerjanya dengan berupaya mengelola kredit yang disalurkan secara lebih hati-hati. Dalam perusahaan perbankan peran Loan to Deposit Ratio (LDR) sebagai salah satu ukuran likuiditas kinerja keuangan sangat penting. Studi Damara (2015) menyatakan bahwa LDR berpengaruh positif terhadap nilai perusahaan perbankan. LDR digunakan sebagai suatu indikator untuk mengetahui tingkat kerawanan suatu bank (Wardiah, 2013). Tujuan perhitungan dari LDR adalah untuk mengetahui serta menilai sampai seberapa jauh perusahaan bank memiliki kondisi sehat dalam menjalankan kegiatan usahanya. Semakin banyak kredit yang disalurkan maka semakin tinggi juga pendapatan bunga bank, karena kredit bagi perusahaan perbankan masih menjadi satu-satunya sumber pendapatan yang sangat menentukan besar kecilnya laba yang diperoleh. Praktik tata kelola bank yang baik akan memberi peluang kepada bank untuk melakukan ekspansi kredit baru lagi yang akan meningkatkan kinerja keuangan dan akan berpengaruh terhadap nilai perusahaan. Dengan demikian tata kelola bank yang baik dalam mendorong peningkatan nilai perusahaan akan semakin diperkuat jika bank mampu mengelola kredit secara efektif melalui keseimbangan antara jumlah kredit yang disalurkan dengan jumlah simpanan yang direpresentasikan dengan rasio Loan to Deposit Ratio (LDR). Berdasarkan argumentasi tersebut maka diajukan hipotesis sebagai berikut :

$\mathrm{H}_{4 \mathrm{a}}$ : LDR memperkuat pengaruh kepemilikan institusional terhadap nilai perusahaan.

$\mathrm{H}_{4 \mathrm{~b}}$ : LDR memperkuat pengaruh kepemilikan manajerial terhadap nilai perusahaan.

$\mathrm{H}_{4 \mathrm{a}}$ : LDR memperkuat pengaruh komisaris independen terhadap nilai perusahaan.

\section{Metode Penelitian}

Penelitian ini menggunakan pendekatan kuantitatif dengan menguji hubungan kausalitas antara variabel independen terhadap variabel dependen. Hal ini dikarenakan penelitian ini menjelaskan hubungan dari good corporate governance terhadap nilai perusahaan dengan peran kinerja keuangan yang diproksikan dengan loan to deposit ratio (LDR) sebagai pemoderasi serta pengujian variabel kontrol dengan menggunakan variabel ukuran perusahaan dan reputasi bank. 
Populasi dari penelitian ini adalah perusahaan perbankan go public yang terdaftar di BEI dengan sampel diambil berdasarkan metode purposive sampling dengan kriteria sebagai berikut (1) perusahaan sektor perbankan yang listing di Bursa Efek Indonesia selama tahun 2015-2018; (2) mempublikasikan pada laporan tahunan perusahaan (annual report) dan (3) informasi lengkap mengenai variabel yang diteliti selama periode pengamatan.

Variabel independen dalam penelitian ini adalah kepemilikan intitusional, kepemilikan manajerial, komisaris independen sebagai proksi dari corporate governance, serta nilai perusahaan sebagai variabel dependen. Variabel LDR merupakan variabel pemoderasi, sedangkan ukuran dan reputasi bank merupakan variabel kontrol. Berikut ini adalah pengukuran dari masing-masing variabel penelitian :

a. Nilai Perusahaan

Nilai perusahaan diukur dengan rasio pasar yaitu Tobin's $Q$. Rasio Tobin's $Q$ untuk mengukur nilai perusahaan dapat memasukkan semua unsur hutang dan modal saham perusahaan, tidak hanya saham biasa saja dan tidak hanya ekuitas perusahaan yang dimasukkan namun seluruh aset perusahaan.

$$
q=\frac{(M V S+D)}{T A}
$$

b. Kepemilikan Institusional

Kepemilikan institusional merupakan proporsi kepemilikan saham oleh institusi seperti perusahaan swasta, perusahaan lembaga keungan, dan dana pensiun. Kepemilikan institusional diukur dengan menggunakan rasio antara jumlah lembar saham yang dimiliki oleh institusi terhadap jumlah lembar saham perusahaan yang beredar secara keseluruhan.

$$
\text { Kepemilikan Institusional }=\frac{\text { Kepemilikan saham institusional }}{\text { Jumlah saham yang beredar }}
$$

c. Kepemilikan Manajerial

Kepemilikan manajerial merupakan kepemilikan saham oleh pihak manajemen perusahaan. Kepemilikan manajerial diukur dengan menggunakan rasio antara jumlah saham yang dimiliki manajer atau direksi dan dewan komisaris terhadap total saham yang beredar.

$$
\text { Kepemilikan Manajerial }=\frac{\text { Kepemilikan saham manajerial }}{\text { Total saham yang beredar }}
$$

d. Komisaris Independen

Komisaris independen adalah dewan komisaris yang berasal dari luar perusahaan yang bersifat independen dan tidak memiliki kepentingan pribadi pada perusahaan. Komisaris independen diukur dengan persentase total komisaris independen terhadap jumlah total dewan komisaris yang ada di perusahaan.

$$
\text { Komisaris Independen }=\frac{\text { Jumlah } \text { komisaris independen }}{\text { Total anggota dewan komisaris }}
$$

e. Loan to Deposit Ratio

Kinerja keuangan menggunakan rasio dalam mengukur tingkat likuiditas bank yang diproksikan dengan Loan to Deposit Ratio (LDR). Hal ini dikarenakan LDR dapat mengukur kemampuan manajemen bank dalam mengembangkan penyaluran kredit yang dananya berasal dari dana pihak ketiga dengan rumus sebagai berikut: 


$$
L D R=\frac{\text { Jumlah kredit yang diberikan }}{\text { Dana pihak ketiga }} \times 100 \%
$$

\section{f. Ukuran Perusahaan}

Ukuran perusahaan dicerminkan dengan total aset yang menggambarkan seberapa besar dana yang dikelola dan kompleksitasnya. Perhitungan ukuran perusahaan menggunakan skala rasio yang dilakukan dengan cara melogaritmakan total asset bank.

$$
\text { Size }=\text { Ln Total aset }
$$

g. Reputasi Bank

Reputasi bank dihitung dengan jumlah penghargaan yang didapatkan bank.

$$
\text { Reputasi Bank = Jumlah penghargaan yang diterima }
$$

Analisis data dilakukan melalui uji statistik deskriptif, uji asumsi klasik dan Moderated Regression Analysis (MRA). Statistik deskriptif menjelaskan karakteristik variabel penelitian, yaitu jumlah pengamatan, nilai minimum, nilai maksimum, nilai rata-rata (mean), dan standar deviasi pada variabel-variabel yang diteliti yaitu nilai perusahaan, good corporate governance, loan to deposit ratio (LDR), ukuran perusahaan dan reputasi bank. Uji Asumsi Klasik dilakukan melalui pengujian normalitas, multikolinearitas, autokolerasi dan heteroskedastisitas. Teknik analisis data yang digunakan dalam penelitian ini adalah uji Moderated Regression Analysis (MRA) yang merupakan suatu uji yang dilakukan untuk mengetahui apakah variabel kinerja keuangan yang diukur dengan LDR mampu memoderasi pengaruh good corporate governance terhadap nilai perusahaan dengan menginternalisasi variabel kontrol yaitu ukuran perusahaan dan reputasi bank. Model persamaan matematis yang diuji adalah sebagai berikut :

$$
Y=a+b_{1} X_{1}+b_{2} X_{2}+b_{3} X_{3}+b_{4} X_{4}+b_{5} X_{5}+b_{6} X_{6}+b_{7} X_{1} X_{4}+b_{8} X_{2} X_{4}+b_{9} X_{3} X_{4}+e
$$

Keterangan :

$\mathrm{Y}=$ Nilai Perusahaan

a $\quad=$ Konstanta

$\mathrm{b}_{1-9} \quad=$ Koefisien regresi

$\mathrm{X}_{1} \quad=$ Kepemilikan Institusional

$\mathrm{X}_{2} \quad=$ Kepemilikan Manajerial

$\mathrm{X}_{3}=$ Komisaris Independen

$\mathrm{X}_{4} \quad=\mathrm{LDR}$

$\mathrm{X}_{5} \quad=$ Ukuran Perusahaan

$\mathrm{X}_{6} \quad=$ Reputasi bank

\section{Hasil dan Pembahasan}

Pengujian dilakukan pada perusahaan perbankan yang terdapat di BEI periode 2015 sampai dengan 2018 diperoleh 172 observasi yang memenuhi kriteria sebagai sampel penelitian. Kemudian dari 172 sampel tersebut, sebanyak 5 sampel dikeluarkan karena terdeteksi adanya outlier. Munculnya data outlier karena memiliki nilai ekstrim dan tidak dapat terdistribusi secara normal. Data outlier yang berjumlah 5 sampel observasi tersebut dikeluarkan agar dapat memenuhi asumsi klasik yang mendasari regresi linier berganda. sehingga sampel yang digunakan untuk menguji hipotesis berjumlah 167 sebagaimana disajikan pada tabel 1 berikut ini : 
Tabel 1. Seleksi Penentuan Jumlah Sampel

\begin{tabular}{lc}
\hline \multicolumn{1}{c}{ Keterangan } & Jumlah \\
\hline Perusahaan perbankan terdaftar di Bursa Efek Indonesia & 45 \\
Perusahaan tidak terdaftar di BEI selama tahun 2015-2018 & $\frac{(2)}{43}$ \\
Total sampel & 172 \\
Total observasi selama periode 2015-2018 (dikalikan 4 tahun) & $\underline{5}$ \\
Data Outlier & 167 \\
Total sampel observasi &
\end{tabular}

\section{Statistik Deskriptif}

Hasil pengujian statistik deskriptif disajikan pada tabel 2. Nilai perusahaan diukur menggunakan rasio Tobins ' $Q$. Nilai Tobins ' $Q$ terendah sebesar 0,833 dan tertinggi sebesar 1,670. Rata-rata nilai perusahaan sebesar 1,076 yaitu ada kecenderungan nilai rata-rata pada nilai perusahaan mendekati nilai maksimal, yang berarti rata-rata perusahaan memiliki kinerja yang baik dan mampu untuk meningkatkan nilai perusahaan. Kepemilikan institusional memiliki nilai terendah sebesar $0 \%$ dan nilai tertinggi sebesar $100 \%$. Rata-rata nilai kepemilikan institusional sebesar 70,4\%, artinya setiap perusahaan sampel didominasi oleh keberadaan dari investor dari pihak institusi. Kepemilikan manajerial memiliki nilai terendah sebesar $0 \%$ dan nilai tertinggi sebesar $72,1 \%$. Rata-rata nilai kepemilikan manajerial sebesar $3,1 \%$, artinya perusahaan sampel memiliki persentase yang relatif kecil pada saham yang dimiliki oleh pihak manajemen perusahaan.

Tabel 2. Statistik Deskriptif

\begin{tabular}{llrrrr}
\hline \multicolumn{1}{c}{ Variabel } & $\mathrm{N}$ & Min. & Max. & Mean & Std. Deviation \\
\hline Nilai Perusahaan $(\mathrm{Y})$ & 167 & 0.833 & 1.670 & 1.076 & 0.153 \\
Kep. Institusional $\left(\mathrm{X}_{1}\right)$ & 167 & 0.000 & 1.000 & 0.704 & 0.207 \\
Kep. Manajerial $\left(\mathrm{X}_{2}\right)$ & 167 & 0.000 & 0.721 & 0.031 & 0.107 \\
Kom. Independen $\left(\mathrm{X}_{3}\right)$ & 167 & 0.125 & 1.000 & 0.568 & 0.122 \\
LDR $\left(\mathrm{X}_{4}\right)$ & 167 & 0.420 & 1.125 & 0.846 & 0.120 \\
Ukuran Perusahaan $\left(\mathrm{X}_{5}\right)$ & 167 & 11.823 & 15.113 & 13.460 & 0.803 \\
Reputasi Bank $\left(\mathrm{X}_{6}\right)$ & 167 & 0.000 & 87.000 & 13.497 & 15.110 \\
\hline
\end{tabular}

Besarnya nilai komisaris independen memiliki nilai terendah sebesar $12,5 \%$ dan nilai tertinggi sebesar 100\%. Rata-rata nilai komisaris independen sebesar 56,8\%, artinya dewan komisaris indepeden dari keseluruhan anggota dewan komisaris yang ada dalam sususan dewan komisaris perusahaan sampel telah sesuai dengan peraturan Otoritas Jasa Keuangan No.55/POJK.03/2016 yaitu jumlah komisaris independen wajib paling sedikit 50\%. LDR memiliki nilai terendah sebesar $42 \%$ dan nilai tertinggi sebesar $112,5 \%$. Rata-rata nilai LDR sebesar $84,6 \%$, artinya nilai LDR perusahaan sampel memenuhi persyaratan batas aman dari besaran nilai LDR yang telah ditetapkan oleh Bank Indonesia No.18/14/PBI/2016 sebesar $80 \%-92 \%$.

Ukuran perusahaan memiliki nilai terendah sebesar 11,823 8 dan nilai tertinggi sebesar 15,113 . Rata-rata nilai ukuran perusahaan sebesar 13,460 artinya pada perusahaan sampel memiliki skala ukuran perusahaan yang cukup besar sehingga perusahaan memiliki akses yang lebih besar untuk mendapat sumber pendanaan dari berbagai sumber. Reputasi bank memiliki nilai terendah sebesar 0 dimiliki oleh 18 perusahaan sampel karena tidak mendapatkan penghargaan pada tahun 2015 sampai 2018 dan nilai tertinggi sebesar 87. Ratarata nilai reputasi bank sebesar 13,497 artinya secara keseluruhan pada perusahaan sampel terdapat beberapa perusahaan yang mendapatkan penghargaan yang relatif sedikit dan yang 
banyak mendapatkan penghargaan rata-rata diperoleh oleh perusahaan bank yang berbadan umum milik negara atau bank BUMN karena telah banyak dikenal oleh masyarakat luas.

\section{Hasil Uji Asumsi Klasik}

Pengujian kualitas data melalui uji asumsi klasik dilakukan melalui uji normalitas, multikolinearitas, autokolerasi dan heteroskedastisitas.

\begin{tabular}{lr}
\multicolumn{2}{c}{ Tabel 3. Hasil Uji Normalitas } \\
\hline \multicolumn{2}{c}{ Uji Kolmogorov-Smirnov } \\
\hline $\mathrm{N}$ & 167 \\
Kolmogorov-Smirnov Z & 1.315 \\
Asymp. Sig. (2-tailed) & .063 \\
\hline
\end{tabular}

Dari hasil uji normalitas dengan uji Kolmogorov-Smirnov didapatkan hasil Asymp. Sig. (2-tailed) sebesar 0,063 yang lebih besar dari 0,05 sebagaimana ditunjukkan pada tabel 3 . Dengan demikian dapat disimpulkan bahwa seluruh data dalam penelitian memiliki distribusi nilai residual secara normal. Hasil pengujian multikolinieritas menunjukkan bahwa nilai tolerance pada masing-masing variabel lebih besar dari 0,1 , demikian pula dengan nilai Variance Inflation Factor (VIF) masing-masing variabel lebih kecil dari 10 sebagaimana ditunjukkan pada tabel 4 . Hal ini berarti hasil uji tidak terdapat masalah multikoleniaritas.

Tabel 4. Hasil Uji Multikolinearitas

\begin{tabular}{lcl}
\hline Variabel & Tolerance & VIF \\
\hline Kep. Institusional $\left(\mathrm{X}_{1}\right)$ & 0.391 & 2.559 \\
Kep. Manajerial $\left(\mathrm{X}_{2}\right)$ & 0.186 & 8.596 \\
Kom. Independen $\left(\mathrm{X}_{3}\right)$ & 0.638 & 1.567 \\
LDR $\left(\mathrm{X}_{4}\right)$ & 0.810 & 1.235 \\
Ukuran Perusahaan $\left(\mathrm{X}_{5}\right)$ & 0.750 & 1.333 \\
Reputasi Bank $\left(\mathrm{X}_{6}\right)$ & 0.667 & 1.500 \\
Kep.Institusional*LDR $\left(\mathrm{X}_{1} \mathrm{X}_{4}\right)$ & 0.489 & 2.043 \\
Kep. Manajeial*LDR $\left(\mathrm{X}_{2} \mathrm{X}_{4}\right)$ & 0.185 & 8.810 \\
Kom. Independen*LDR $\left(\mathrm{X}_{3} \mathrm{X}_{4}\right)$ & 0.679 & 1.473 \\
\hline
\end{tabular}

Dari hasil uji autokorelasi pada tabel 5 menunjukkan bahwa nilai uji Durbin Watson sebesar 2,097. Nilai dU untuk jumlah sampel 167 dengan jumlah variabel sebanyak 10 yaitu sebesar 1,86145. Maka nilai 4-dU adalah 2,13855, sehingga hasil uji autokolerasinya adalah $\mathrm{dU}<\mathrm{d}<(4-\mathrm{dU})$, yaitu $1,86145<2,097<2,13855$. Dengan demikian dapat dinyatakan bahwa berarti koefisien regresi bebas dari gangguan autokolerasi.

Tabel 5. Hasil Uji Autokorelasi

\begin{tabular}{llcccc}
\hline $\mathbf{T}$ & $\mathbf{k}$ & $\mathbf{d L}$ & $\mathbf{d U}$ & $\mathbf{( 4 - d U )}$ & Durbin-Watson \\
\hline 10 & 167 & 1.63487 & 1.86145 & 2.13855 & 2.097 \\
\hline
\end{tabular}

Berdasarkan hasil pengujian heteroskedastisitas menunjukkan bahwa nilai signifikansi masing-masing variabel lebih besar dari 0,05 sehingga dapat disimpulkan bahwa model regresi bebas dari gejala heteroskedastisitas sebagaimana disajikan pada tabel 6 berikut ini : 
Tabel 6. Uji Heterokedastisitas

\begin{tabular}{lc}
\hline Variabel & Signikansi \\
\hline Kep. Institusional $\left(\mathrm{X}_{1}\right)$ & .130 \\
Kep. Manajerial $\left(\mathrm{X}_{2}\right)$ & .609 \\
Kom. Independen $\left(\mathrm{X}_{3}\right)$ & .618 \\
LDR $\left(\mathrm{X}_{4}\right)$ & .414 \\
Ukuran Perusahaan $\left(\mathrm{X}_{5}\right)$ & .130 \\
Reputasi Bank $\left(\mathrm{X}_{6}\right)$ & .055 \\
Kep.Institusional*LDR $\left(\mathrm{X}_{1} \mathrm{X}_{4}\right)$ & .198 \\
Kep. Manajeial*LDR $\left(\mathrm{X}_{2} \mathrm{X}_{4}\right)$ & .443 \\
Kom. Independen*LDR $\left(\mathrm{X}_{3} \mathrm{X}_{4}\right)$ & .731 \\
\hline
\end{tabular}

\section{Hasil Pengujian Hipotesis dan Pembahasan}

Hasil pengujian terhadap uji ketepatan model dan koefisien determinasui disajikan pada tabel 7. Hasil uji nilai $\mathrm{F}$ hitung sebesar 3,159 dengan tingkat signifikansi $0,002<0,05$ menunjukkan bahwa kepemilikan institusional, kepemilikan manajerial dan komisaris independen, serta interaksi kepemilikan institusional, kepemilikan manajerial dan komisaris independen dengan LDR secara signifikan mampu mempengaruhi nilai perusahaan. Dapat disimpulkan bahwa model penelitian ini dapat dikatakan layak digunakan sebagai model prediksi. Berdasarkan hasil uji diatas menunjukkan nilai koefisien determinasi sebesar 0,105 yang berarti 10,5\% variasi nilai perusahaan dapat dijelaskan oleh kepemilikan institusional, kepemilikan manajerial, komisaris independen, dan LDR. Sedangkan sebesar 89,5\% dapat dijelaskan oleh variabel-variabel lain di luar model penelitian ini, seperti komite audit, komite pemantau risiko dan kualitas audit.

Tabel 7. Koefisien Determinasi dan F test

\begin{tabular}{lrrr}
\hline Model & Adjusted R Square & F & \multicolumn{2}{c}{ F Sig } \\
\hline 1 & 0.105 & 3.159 & 0.002 \\
\hline
\end{tabular}

a. Dependent Variable: Y

Untuk menguji hipotesis yang diajukan maka digunakan analisis regresi moderasi yang hasilnya disajikan pada tabel 8 . Berdasarkan tabel 8 dapat diketahui hanya variabel X5 dan X6 atau variabel kontrol yang signifikan dalam mempengaruhi nilai perusahaan, sedangkan variabel lainnya tidak signifikan. Hal ini menunjukkan bahwa variabel kinerja keuangan yang diukur dengan Loan to Deposit Ratio atau LDR tidak terbukti mampu memoderasi hubungan antara good corporate governance dan nilai perusahaan.

Tabel 8. Hasil Uji Moderated Regression Analysis

\begin{tabular}{clrr}
\hline & & \multicolumn{2}{c}{ Unstandardized Coefficients } \\
\cline { 2 - 3 } Model & \multicolumn{1}{c}{ B } & \multicolumn{1}{c}{ Std. Error } & \multicolumn{1}{c}{ Sig. } \\
\hline 1 (Constant) & 2.065 & .576 & .000 \\
X1 & .278 & .527 & .599 \\
X2 & .062 & .651 & .924 \\
X3 & .208 & .593 & .725 \\
X4 & -.054 & .572 & .924 \\
X5 & -.082 & .023 & .001 \\
X6 & .005 & .001 & .000 \\
X1X4 & -.146 & .637 & .818 \\
X2X4 & -.272 & .965 & .779 \\
X3X4 & -.265 & .705 & .707 \\
\hline
\end{tabular}




\section{Pengaruh Kepemilikan Institusional Terhadap Nilai Perusahaan}

Hipotesis pertama yang diajukan dalam penelitian ini adalah kepemilikan institusional berpengaruh positif terhadap nilai perusahaan. Hasil pengujian menunjukkan nilai signifikansi sebesar 0,599 >0,005 dengan nilai koefisien beta sebesar 0,278, sehingga $\mathrm{H}_{1}$ ditolak yang menjelaskan bahwa kepemilikan institusional berpengaruh positif tidak signifikan terhadap nilai perusahaan. Hasil penelitian ini sejalan dengan studi Rohiman dan Rahayu (2015), Azzahrah (2014), serta Dewi dan Nugrahanti (2014) yang mengatakan bahwa kepemilikan institusional tidak berpengaruh terhadap nilai perusahaan. Hal ini menunjukkan bahwa kepemilikan institusional yang tinggi tidak selalu diikuti oleh nilai perusahaan yang tinggi juga. Begitu pun sebaliknya, kepemilikan institusional yang rendah tidak selalu diikuti oleh nilai perusahaan yang rendah juga. Namun demikian hasil penelitian ini berbeda dengan Wida dan Suartana (2014) serta Octavia (2017) yang mengatakan bahwa kepemilikan institusional berpengaruh positif terhadap nilai perusahaan karena kepemilikan institusional yang semakin tinggi ataupun rendah dapat mempengaruhi kepercayaan investor dan berdampak pada nilai perusahaan.

Jumlah pemegang saham institusi yang besar belum efektif dalam memonitor perilaku dalam perusahaan untuk meningkatkan nilai perusahaan. Hal ini dibuktikkan dengan kepemilikan institusional yang tinggi tidak selalu diikuti oleh nilai perusahaan yang tinggi juga. Pada hasil statistik deskriptif yang menjelaskan bahwa kepemilikan institusional pada perusahaan sampel memiliki jumlah kepemilikan tertinggi sebesar 100\% dan terendah sebesar $0 \%$. Kepemilikan saham pada perusahaan sampel sektor perbankan didominasi oleh lembagalembaga keuangan, karena kepemilikan saham yang dimiliki oleh institusi pada perusahaan sampel memiliki nilai rata-rata sebesar 70,4\%. Kepemilikan institusional didominasi oleh lembaga-lembaga keuangan karena investor pada lembaga keuangan lebih tertarik pada pencapaian jangka pendek yang dilihat dari kinerja keuangannya dibandingkan dengan pencapaian jangka panjang yang dilihat dari nilai perusahaannya, sehingga tidak berpengaruh terhadap nilai perusahaan. Kepemilikan bank yang dimiliki oleh institusi atau lembaga melakukan pengawasan secara kolektif karena memiliki suara terbanyak dalam kepemilikan saham perusahaan sehingga apabila kepemilikan institusi dapat berperan sebagai kolektif monitoring, hal tersebut diharapkan dapat meningkatkan nilai perusahaan.

\section{Pengaruh Kepemilikan Manajerial Terhadap Nilai Perusahaan}

Hipotesis kedua yang diajukan dalam penelitian ini adalah kepemilikan manajerial berpengaruh positif terhadap nilai perusahaan. Hasil pengujian menunjukkan nilai signifikansi sebesar 0,924 >0,005 dengan nilai koefisien beta sebesar 0,062, sehingga $\mathrm{H}_{2}$ ditolak yang menjelaskan bahwa kepemilikan manajerial berpengaruh positif dan tidak signifikan terhadap nilai perusahaan. Hasil penelitian ini sejalan dengan studi Dewi dan Nugrahanti (2014), Wida dan Suartana (2014), serta Syafitri dkk (2018) yang menyatakan bahwa kepemilikan manajerial tidak berpengaruh terhadap nilai perusahaan. Rendahnya saham yang dimiliki oleh manajemen mengakibatkan pihak manajemen belum merasa ikut memiliki perusahaan sehingga tidak semua keuntungan dapat dinikmati oleh manajemen yang menyebabkan pihak manajemen termotivasi untuk memaksimalkan kepentingannya sendiri. Berbeda dengan Octavia (2017) yang mengatakan bahwa kepemilikan manajerial berpengaruh terhadap nilai perusahaan, yang dimana manajer lebih banyak mengetahui situasi dan kondisi perusahaan dibandingkan dengan pemilik, sehingga manajer selalu dituntut untuk memberikan keuntungan bagi pemilik maupun pemegang saham. 
Dalam agency problem, agent mempunyai lebih banyak informasi mengenai kapasitas lingkungan kerja dan perusahaan secara keseluruhan, sedangkan principal tidak mempunyai informasi yang cukup tentang kinerja agent. Ketika tidak semua keadaan diketahui oleh semua pihak, maka konsekuensi-konsekuensi tertentu tidak dapat dipertimbangkan oleh pihak-pihak tersebut, yang mengakibatkan adanya ketidakseimbangan informasi. Hal tersebut juga memungkinkan manajer lebih mengutamakan kepentingan pribadinya (self-interest) dalam mengambil keuntungan. Dalam menangani perilaku manajer tersebut, perusahaan memberikan beberapa jumlah saham perusahaan untuk dimiliki oleh pihak manajer agar manajer dapat bekerja sesuai dengan principal dan dapat meningkatkan kesejahteraan bagi pihak manajemen. Namun demikian hasil penelitian mengungkapkan kepemilikan manajerial pada perusahaan sampel cenderung rendah, dapat dilihat dari hasil statistik deskriptifnya ratarata hanya sebesar 3,1\%. Dengan jumlah rata-rata kepemilikan saham oleh pihak manajemen yang hanya sebesar 3,1\% tidak dapat membuat kinerja manajer meningkat dan belum efektif dalam mengelola perusahaan dalam rangka meningkatkan nilai perusahaan. Dengan demikian, kepemilikan manajerial yang rendah belum mampu untuk meningkatkan nilai perusahaan.

\section{Pengaruh Komisaris Independen Terhadap Nilai Perusahaan}

Hipotesis ketiga yang diajukan dalam penelitian ini adalah komisaris independen berpengaruh positif terhadap nilai perusahaan. Hasil pengujian menunjukkan nilai signifikansi sebesar 0,725 >0,005 dengan nilai koefisien beta positif sebesar 0,208, sehingga $\mathrm{H}_{3}$ ditolak yang menjelaskan bahwa komisaris independen berpengaruh positif namun tidak signifikan terhadap nilai perusahaan. Hasil penelitian ini mendukung hasil penelitian Azzahrah (2014) dan Fiadicha (2016) yang menyatakan bahwa komisaris independen tidak berpengaruh terhadap nilai perusahaan, karena tinggi atau rendahnya jumlah komisaris independen yang terdapat dalam perusahaan dinilai belum cukup efektif untuk melakukan monitoring terhadap manajer perusahaan. Berbeda dengan Dewi dan Nugrahanti (2014), dan Muryati dan Suardikha (2014) yang mengatakan tinggi rendahnya proporsi dewan komisaris independen berpengaruh pada nilai perusahaan sehingga komisaris independen berpengaruh positif terhadap nilai perusahaan.

Menurut peraturan Otoritas Jasa Keuangan No.55/POJK.03/2016 bahwa jumlah komisaris independen wajib paling sedikit 50\% dari jumlah seluruh anggota dewan komisaris untuk menjadi suatu keharusan bagi perusahaan publik memiliki komisaris independen dalam organ perusahaan. Pada penelitian ini membuktikan keberadaan komisaris independen tidak berpengaruh terhadap nilai perusahaan. Hasil uji statistik deskriptif pada proporsi komisaris independen, nilai rata-rata pada perusahaan sampel sudah berada di atas jumlah minimal $50 \%$ dari total dewan komisaris yang dimiliki perusahaan, yaitu sebesar 56,8\%. Hal ini mengindikasikan bahwa adanya komisaris independen dalam perusahaan dinilai belum cukup efektif untuk melakukan pemantauan terhadap manajer dalam perusahaan tersebut. Pengangkatan dewan komisaris independen mungkin hanya dilakukan untuk pemenuhan regulasi, tetapi faktanya belum mampu untuk mendorong strategi dan kebijakan untuk meningkatkan nilai perusahaan pada perusahaan.

\section{Peran Kinerja Keuangan Dalam Memoderasi Pengaruh Good Corporate Governance Terhadap Nilai Perusahaan}

Hasil pengujian pada variabel interaksi kinerja keuangan belum mampu menunjukkan pengaruh good corporate governance yang diproksikan dengan kepemilikan institusional, 
kepemilikan manjerial dan komisaris independen terhadap nilai perusahaan. Uji interaksi LDR terhadap kepemilikan institusional dengan LDR menunjukkan nilai signifikansi sebesar $0,818>0,05$ dengan nilai koefisien beta sebesar -0,146 yang menunjuk arah negatif. Hasil pengujian tersebut menyatakan bahwa LDR tidak dapat memperkuat pengaruh kepemilikan institusional terhadap nilai perusahaan, sehingga hipotesis ditolak. Hasil pengujian ini didukung oleh penelitian yang dilakukan oleh Rochmah (2017) yang mengindikasikan bahwa likuiditas tidak dipertimbangkan oleh pihak eksternal perusahaan dalam melakukan penilaian sebuah perusahaan dan tidak memiliki pengaruh yang signifikan terhadap perubahan harga saham sebuah perusahaan. Keberadaan kepemilikan institusional menjadi mekanisme monitoring yang efektif dalam setiap keputusan yang diambil oleh manajer, dilakukan untuk mensubstansi biaya keagenan sehingga biaya keagenan menurun dan nilai perusahaan dapat meningkat. Kapasitas pemegang saham institusi diduga hanyalah sebatas memberikan modal dan memberikan pengawasan terhadap pencapaian profitabilitas dari pemanfaatan ekuitas perusahaan sampel. Keberadaan kepemilikan institusional bukan dipengaruhi karena besar atau kecilnya rasio LDR yang terdapat pada perusahaan. Jadi penelitian ini menunjukkan LDR tidak dapat memperkuat pengaruh kepemilikan institusional terhadap nilai perusahaan.

Hasil pengujian tentang pengaruh positif LDR terhadap hubungan kepemilikan manajerial pada nilai perusahaan menunjukkan hasil bahwa variabel interaksi kepemilikan manajerial dengan LDR menunjukkan nilai signifikansi sebesar 0,779 $>0,05$ dengan nilai koefisien beta sebesar -0,272 yang menunjuk arah negatif. Hasil pengujian tersebut menyatakan bahwa LDR tidak dapat memperkuat pengaruh kepemilikan manajerial terhadap nilai perusahaan, sehingga hipotesis ditolak. Hasil pengujian ini didukung oleh penelitian yang dilakukan oleh Andriyan (2010), tidak berpengaruhnya kepemilikan manajerial terhadap rasio LDR karena jumlah kredit yang disalurkan oleh perusahaan lebih dipengaruhi oleh tingkat suku bunga pinjaman yang berlaku, di mana suku bunga pinjaman ini lebih banyak ditentukan oleh BI sebagai regulator. Hal ini dikarenakan kepemilikan manajemen pada perusahaan sampel cenderung masih rendah yang menyebabkan manajemen tidak memiliki pengendalian yang cukup atas penyaluran kredit, permodalan dan likuiditas perusahaan sampel, sehingga tinggi atau rendahnya rasio LDR pada perusahaan sampel tidak akan mempengaruhi kepemilikan saham manajerial. Perusahaan dengan kepemilikan manajerial yang tinggi seharusnya mempunyai konflik keagenan yang rendah yang menyebabkan biaya keagenan pun menjadi rendah, karena dalam konflik keagenan yang rendah dapat direfleksikan pada besarnya persentasi LDR yang sesuai dengan ketentuan yang telah disyaratkan oleh BI (Andriyan, 2010). Namun pada penelitian ini bahwa kepemilikan saham yang dimiliki oleh pihak manajemen tidak dapat diperkuat oleh besar atau kecilnya nilai LDR yang dihasilkan oleh perusahaan.

Hipotesis tentang pengaruh LDR dalam memoderasi pengaruh komisaris independen pada nilai perusahaan menunjukkan hasil pengujian pada variabel interaksi komisaris independen dengan LDR menunjukkan nilai signifikansi sebesar 0,707 $>0,05$ dengan nilai koefisien beta sebesar -0,265 yang menunjuk arah negatif. Hasil pengujian tersebut menyatakan bahwa LDR tidak dapat memperkuat pengaruh komisaris independen terhadap nilai perusahaan, sehingga hipotesis ditolak. Hasil pengujian ini didukung oleh penelitian yang dilakukan oleh Hutami dan Marsono (2015), yang menunjukkan bahwa banyaknya dewan komisaris independen pada perusahaan sampel tidak dapat menyebabkan peningkatan pada kemampuan perusahaan dalam mengelola besaran modal sendiri, aspek likuiditas dan 
tingkat profitabilitas. Nilai LDR yang dimiliki oleh perusahaan sampel tidak mempengaruhi jumlah dari komisaris independen yang terdapat didalam perusahaan. Menurut Bank Indonesia No.18/14/PBI/2016, suatu perusahaan bank dianggap sehat apabila besar batas bawah LDR sebesar $80 \%$ dan batas atas LDR sebesar 92\%. Jika nilai LDR diatas $92 \%$ akan menyebabkan kredit macet karena memakai seluruh dana yang dimiliki untuk pinjaman namun tidak menyisahkan dana yang telah digunakan sebagai sumber likuiditasnya, sedangkan bila nilai LDR dibawah $80 \%$ maka akan terjadi pengendapan dana berlebih yang tidak dapat tersalurkan dengan berupa pinjaman. Dengan demikian kenaikan atau penurunan nilai LDR pada perusahaan tidak diikuti juga dengan bertambahnya atau berkurangnya komisaris independen pada perusahaan sampel. Jumlah dari komisaris independen didalam perusahaan telah diatur dalam peraturan Otoritas Jasa Keuangan No.55/POJK.03/2016 bahwa jumlah komisaris independen wajib paling kurang 50\%. Oleh karena itu keberadaan dewan komisaris independen pada perusahaan lebih karena alasan pemenuhan regulasi.

\section{Hasil Pengujian Variabel Kontrol}

Hasil pengujian terhadap variabel kontrol ukuran perusahaan dan reputasi perusahaan menunjukkan hasil yang signifikan. Hasil pengujian variabel kontrol ukuran perusahaan menunjukkan nilai signifikansi sebesar $0,001<0,05$ dengan nilai koefisien beta sebesar 0,082 yang menunjuk arah negatif. Hal ini menunjukkan bahwa ukuran perusahaan berpengaruh negatif nilai perusahaan. Ukuran perusahaan dilihat dari total aset yang dimiliki oleh perusahaan yang dapat dipergunakan untuk kegiatan operasi perusahaan. Pada neraca bank, aktiva menunjukkan posisi penggunaan dana melalui kredit yang disalurkan. Jika perusahaan memiliki total aset yang besar, pihak manajemen lebih leluasa dalam mempergunakan aset yang ada di perusahaan tersebut. Ukuran perusahaan merupakan besarnya kekayaan yang dimiliki oleh suatu perusahaan. Semakin besarnya ukuran perusahaan perbankan juga memiliki peluang yang lebih besar dalam meningkatkan risiko yang harus ditanggung oleh pihak bank. Hal itu terjadi apabila aset yang dimiliki bank tersebut tidak dikelola dan digunakan secara maksimal untuk kegiatan operasional bank, sehingga bank akan berpotensi mengeluarkan biaya pengelolaan aset yang lebih besar. Hal tersebut mengindikasikan bahwa ketika aset bank yang besar tetapi jika tidak dikelola secara efektif dan produktif maka tidak akan berperan dalam meningkatkan nilai perusahaan.

Hasil pengujian terhadap variabel kontrol reputasi perusahaan menunjukkan nilai signifikansi sebesar $0,000<0,05$ dengan nilai koefisien beta sebesar 0,005 yang menunjukkan arah positif. Hal ini menunjukkan bahwa peningkatan reputasi bank berpengaruh positif terhadap nilai perusahaan. Reputasi bank merupakan suatu penilaian yang diberikan oleh konsumen atau masyarakat atas produk maupun layanan yang telah diberikan. Reputasi yang baik akan meningkatkan kredibilitas. Reputasi menjadi sebuah jaminan bahwa yang konsumen dapatkan akan sesuai dengan ekspektasi yang mereka miliki, sehingga hal tersebut dapat meningkatkan nilai perusahaan. Dan juga merupakan suatu bentuk apresiasi terhadap lembaga perbankan di Indonesia yang memiliki kinerja yang baik. Banyaknya penghargaan yang diperoleh akan berpengaruh terhadap nilai perusahaan karena banyaknya penghargaan yang diperoleh artinya banyak konsumen yang percaya terhadap produk ataupun layanan yang diberikan oleh perusahaan, kinerja perusahaan juga dinilai semakin meningkatkan. Bila perusahaan memiliki reputasi yang baik, perusahaan tersebut tentunya akan semakin mendapatkan kepercayaan masyarakat untuk melakukan investasi sehingga akan meningkatkan nilai perusahaan. 


\section{Kesimpulan, Implikasi dan Keterbatasan}

Tujuan dari penelitian ini adalah menguji pengaruh GCG terhadap nilai perusahaan serta pengaruh LDR dalam memoderasi pengaruh good corporate governance (GCG) terhadap nilai perusahaan. Dalam hal ini GCG pada penelitian ini diproksikan dengan kepemilikan institusional, kepemilikan manajerial dan komisaris independen. Sampel yang digunakan adalah badan usaha sektor perbankan yang listing di Bursa Efek Indonesia tahun 2015-2018 berjumlah 167 perusahaan sampel. Hasil penelitian menunjukkan bahwa kepemilikan institusional, kepemilikan manajerial, dan komisaris independen tidak berpengaruh signifikan terhadap nilai perusahaan, namun variabel kontrol ukuran perusahaan dan reputasi bank berpengaruh signifikan terhadap nilai perusahaan. Interaksi kinerja keuangan yang direfleksikan dengan Loan to Deposit Ratio (LDR) tidak mampu memperkuat pengaruh kepemilikan institusional, kepemilikan manajerial, dan komisaris independen terhadap nilai perusahaan.

Hasil penelitian memberikan implikasi tentang pemahaman mengenai perilaku manajemen dalam mengelola perusahaan dengan berpedoman pada prinsip good corporate governance untuk meningkatkan nilai perusahaan. Implikasi praktis penelitian ini dapat dijadikan sebagai bahan masukan dan pertimbangan dalam pengambilan keputusan terutama dalam hal memaksimalkan kinerja keuangan perusahaan dan kemakmuran pemegang saham yang berpengaruh terhadap nilai perusahaan dan pengambilan keputusan investasi bagi para pemegang saham. Implikasi kebijakan yaitu penelitian ini dapat dapat dijadikan sebagai salah satu pertimbangan penentuan kebijakan atau aturan yang berkaitan dengan Surat Edaran No.15/15/DPNP/2013 dan Peraturan Otoritas Jasa Keuangan No.55/POJK.03/2016 tentang penerapan tata kelola bagi bank umum.

Dalam penelitian ini terdapat beberapa keterbatasan, yaitu penelitian ini hanya menggunakan perusahaan jasa pada sektor keuangan yaitu perbankan yang terdaftar pada BEI. Diharapkan untuk penelitian selanjutnya dapat menggunakan sektor keuangan yang lainnya, seperti sektor lembaga pembiayaan, sektor perusahaan efek dan sektor asuransi. Penelitian hanya berfokus pada mekanisme tata kelola perusahaan yang diproksikan dengan kepemilikan institusional, kepemilikan manajerial dan komisaris independen. Diharapkan untuk penelitian selanjutnya dapat menggunakan variabel-variabel lain di luar model penelitian ini, seperti komite audit, komite pemantau risiko dan kualitas audit. Penelitian hanya berfokus pada peran kinerja keuangan yang diukur dengan LDR. Pada penelitian ini, LDR digunakan untuk menilai kondisi kerawanan perusahaan dalam menyalurkan kredit yang merupakan kegiatan usaha utama bagi perusahaan perbankan. Namun terdapat beberapa variabel kinerja keuangan lainnya yang dapat menilai kesehatan suatu bank dalam menjalankan usahanya, seperti CAR, NPL, BOPO ataupun NIM yang dapat digunakan dalam pengujian selanjutnya.

\section{Referensi}

Andriyan, Okky dan Supami. 2010. Pengaruh Mekanisme Corporate Governance Terhadap Kinerja Keuangan Bank Perkreditan Rakyat. Jurnal Akuntansi dan Keuangan Indonesia, 7(2), 187-204

Azzahrah, Zantistya. 2014. Pengaruh Mekanisme Good Corporate Governance Terhadap Nilai Perusahaan (Studi pada sector perbankan yang terdaftar di bursa efek Indonesia tahun 2009-2013). E-Proceeding of Management, 1(3), 203-213. 
Damara, Randy, Sumani, Lilik Farida. 2015. Pengaruh Kinerja Keuangan Terhadap Nilai Perusahaan Dengan Pengungkapan CSR dan GCG Sebagai Variabel Pemoderasi. Artikel Ilmiah Mahasiswa. Hal: 1-10.

Dewi, Laurensia Chintia dan Yeterina Widi Nugrahanti. 2014. Pengaruh Struktur Kepemilikan dan Dewan Komisaris Independen Terhadap Nilai Perusahaan (Studi Pada Perusahaan Industri Barang Konsumsi di BEI Tahun 2011-2013). Kinerja, 18 (1), 6480.

Fiadicha, Fika dan Rahmawati Hanny. 2016. Pengaruh Good Corporate Governance, Corporate Social Responsibility dan Kinerja Keuangan Terhadap Nilai Perusahaan. Jurnal Akuntansi Manajerial, 1 (1), 22-45.

Ghozali, Imam. 2013. Aplikasi Analisis Multivariate dengan IBM SPSS 21 Edisi 7 Semarang: Badan Penerbit Universitas Diponegoro.

Halimah, Sundus Nur dan Euis Komariah. 2017. Pengaruh ROA, NPL, LDR, BOPO Terhadap Nilai Perusahaan Bank Umum. Jurnal Akuntansi, Ekonomi dan Manajemen Bisnis, 5 (1), 14-25.

Halini, Mirawati. 2012. Pengaruh Good Corporate Governance Terhadap Kinerja Perusahaan Perbankan Yang Terdaftar Di Bursa Efek Indoensia Pada Periode 20092011. Skripsi. Fakultas Ekonomi. Universitas Esa Unggul Jakarta.

Hamdani. 2016. Good Corporate Governance: Tinjauan Etika Dalam Praktik Bisnis. Jakarta: Mitra Wacana Media.

Hendratni, Tyhya Whisnu, Nana Nawaslah dn Trisnani Indriati. 2018. Analisis Pengaruh Corporate Governance Terhadap Kinerja Keuangan Sektor Perbankan Yang Terdaftar Di BEI Tahun 2012-2016. Jurnal Riset Manajemen dan Bisnis, 3(1), 37-52.

Hery. 2017. Kajian Riset Akuntansi Mengulas Berbagai Hasil Penelitian Terkini dalam Bidang Akuntansi dan Keuangan. Jakarta: PT. Gramedia.

Hutami, Tyas Rukmi Ken dan Marsono. 2015. Pengaruh Mekanisme Corporate Governance Terhadap Kinerja Keuangan Perbankan (Studi Kasus Pada Bank Pembngunan Daerah di Indonesia Periode 2010-2013). Diponegoro Journal Of Accounting, 4 (1), 153-166.

Ismiawati, Erin. 2018. Pengaruh Value Added dan karakteristik Bank Terhadap Kinerja Keunagan Perbankan. Akurasi Jurnal Studi Akuntansi dan Keuangan, 1 (2), 17-30

Jensen, M.C. \& W. H. Meckling. 1976. heory of the Firm: Managerial Behavior, Agency Costs and Ownership Structure, Journal of Financial Economics, 3 (4), 305-360

Muryati, Ni Nyoman Tri Sariri dan I Made Sadha Suardikha. 2014. Pengaruh Corporate Governance Pada Nilai Perusahaan. E-Jurnal Akuntansi Universitas Udayana, 9 (2), 411-429.

Octavia, Sally Malva. 2017. Pengaruh Kepemilikan Manajerial, dan Kepemilikan Institusional Terhadap Nilai Perusahan. Artikel Ilmiah. Sekolah Tinggi Ekonomi Perbanas Surabaya.

Peraturan Bank Indonesia Nomor 18/14/PBI/2016 Tentang Giro Wajib Minimum Bank Umum Dalam Rupiah dan Valuta Asing Bagi Bank Umum Konvensional. 
Peraturan Otoritas Jasa Keuangan Nomor 55/POJK.03/2016 Tentang Penerapan Tata Kelola Bagi Bank Umum.

Pratiwi, Maya Indah, F.T. Kristanti, D.P.K. Mahardhika. 2016. Pengaruh Kepemilikan Manajerial, Kepemilikan Institusional, dan Leverage Terhadap Nilai Perusahaan. $e$ Proceeding of Management, 3 (3), 3191-3197

Purwaningtyas, Frysa Praditha. 2011. Analisis Pengaruh Mekanisme Good Corporate Governance Terhadap Nilai Perusahaan. Skripsi. Universitas Diponegoro Semarang.

Repi, Switli, Sri Murni dan Decky Adare. 2017. Faktor-faktor Yang Mempengaruhi Nilai Perusahaan Subsektor Perbankan Pada BEI Dalam Menghadapi MEA. Jurnal EMBA. 4 (1), 181-191.

Rochmah, Siti Ainur dan Astri Fitria. 2017. Pengaruh Kinerja Keuangan Terhadap Nilai Perusahaan: Kebijakan Deviden Sebagai Variabel Moderasi. Jurnal Ilmu dan Riset Akuntansi, 6 (3), 998-1017

Rohiman, Viny Oktaviani dan Sri Rahayu. 2015. Kepemilikan Manajerial, Kepemilikan Institusional, Kebijakan Dividen, dan Kebijakan Hutang, Analisis Terhadap Nilai Perusahaan Pada Perusahaan Sektor Jasa Yang Terdaftar Di BEI Periode 2009-2012. EProceeding of Management, 2 (1), 341-348

Suprayitno, G., Sedarnawati Yasni, May Susandy, Aries Susanty, Lien H. Kusumah, Siti Olivia Tito, Zaenal Abidin, Eddya Kusnawijaya, Titik Aryati, Zahroh Naimah, Henni Gusfa, Roedy Poerwanto, Nurul Fajriya, dan Rina Astini. 2016. Laporan Program Riset dan Pemeringkatan Corporate Governance Perception Index 2015. Jakarta: The Indonesian Institute for Corporate Governance.

Surat Edaran Nomor 15/15/DPNP/2013 Tentang Pelaksanaan Good Corporate Governance Oleh Bank Umum Kepada Semua Bank Umum Konvensional Di Indonesia.

Sutedi, Adrian. 2012. Good Corporate Governance. Jakarta: Sinar Grafika.

Syafitri, Tria, Nila Firdausi Nuzula dan Ferina Nurlaily. 2018. Pengaruh Good Corporate Governance Terhadap Nilai Perusahaan. Jurnal Administrasi Bisnis (JAB), 56 (1), 118 126.

Triutari, I Gusti Ayu Intan dan Ni Gusti Putu Wirawati. 2018. Kemampuan Leverage dalam Memoderasi Pengaruh Good Corporate Governance pada Nilai Perusahaan. E-Jurnal Akuntansi Universitas Udayana, 23 (1), 110-129.

Utami, Dena Hesa Puteri dan Muhamad Muslih. 2018. Pengaruh Good Corporate Governance Terhadap Nilai Perusahaan Dengan Kinerja Keuangan Sebagai Variabel Moderasi (Studi kasus pada perusahaan sub sekor asuransi yang terdaftar di bursa efek Indonesia periode 2013-2016). Jurnal AKRAB JUARA, 3 (3), 111-125.

Wardiah, Mia Lasmi. 2013. Dasar-dasar Perbankan. Bandung: CV Pustaka Setia. Bandung.

Wida, Ni Putu dan I Wayan Suartana. 2014. Pengaruh Kepemilikan Manajerial dan Kepemilikan Institusional Pada Nilai Perusahaan. E-Jurnal Akuntansi Universitas Udayana, 9, (3), 575-590. 